\title{
GROWTH OF THE HOLY MOSQUE IN MECCA AND THE FIRST LEGISLATION OF HERITAGE CONSERVATION IN SAUDI ARABIA (1955-2010)
}

\author{
MOHANAD A. ALFELALI \& JOSEP-MARIA GARCIA-FUENTES \\ School of Architecture, Planning \& Landscape, Newcastle University, United Kingdom
}

\begin{abstract}
Mecca city is one of the oldest cities in the world since the first nuclei of the city was laid down more than 3700 years ago by the Prophet Ibrahim, and since that time it has been a sacred city. When the Prophet Mohammed began the call to Islam in $620 \mathrm{AD}$, the city entered a new era in its history to become the most important religious and commercial centre of the Hejaz. The holy Mosque with its courtyard containing the "Ka'aba" is the most important building not only in Mecca but in the Islamic world, and the "Ka'aba" is considered as the heart of the city. The pilgrimage to the city of Mecca (Hajj) is the fifth pillar of Islam, and unlike pilgrimage in other religions, it is a mandatory character for every member of the faithful who can afford it. For this reason, visitor numbers to Mecca have grown exponentially during the last few decades ranging between 1.5-2.5 million pilgrims per season, peaking to 3.2 million pilgrims in $2012 \mathrm{AD}$. This trend is closely connected with the different expansions of the holy mosque since $1955 \mathrm{AD}$, when the first Saudi extension doubled its area. The project was followed by two other major expansions in 1988 and $2010 \mathrm{AD}$. These projects were done at the cost of destroying some historical neighbourhoods where, however, the historical Ottoman portico has been conserved by a royal decree in 1969 AD. This paper will analyse the expansions of the holy Mosque focusing in the projects that took place in the Saudi rule and discussing how these expansions have affected the urban fabric of the city as well as their impacts in the historical area despite the first legislation of heritage conservation policies approved in $1972 \mathrm{AD}$ by using a mixed approach of gathering data through a literature review as a secondary data and the primary sources which include official and non-official reports as well as government and non-government archive records.

Keywords: Mecca, Saudi Arabia, the Holy Mosque, heritage Conservation, Islamic architecture, Islamic heritage, legislation of heritage conservation, expansions of Holy Mosque.
\end{abstract}

\section{INTRODUCTION}

The birth of Islam and the presence of the two holy cities of Mecca and Medina today place the Kingdom of Saudi Arabia at the heart of the Islamic world [1]. Mecca is not like any other cities as it considered as the most important city in the Islamic World visiting by millions of people every year. Each year during the twelfth month of the Islamic calendar, between the eighth and thirteenth day, Muslims from every race and colour come to reach together in the same place and at the same time in order to perform the Hajj which is a mandatory character for every member of the faithful who can afford it as it considers as one of the Islamic pillars.

In $632 \mathrm{AD}$, the prophet Mohammed with 114,000 Muslims performed the first pilgrimage in Islam [2, p. 30]. Since that time, with the spread of Islam far and wide, the number of pilgrims has grown. This has also necessitated the expansion of the Holy Mosque. Thus, a multiple expansion projects have been done to the holy mosque throughout the history In order to meet the increasing demand to visit Mecca. Unfortunately, Increasing the number of visitor was done at the cost of destroying some historical neighbourhood along with ancient buildings around them [3].

This paper attempts to analyse the expansion projects of the holy mosque, particularly, the projects that took place in the Saudi era along with their impacts in the historical area with shedding some light on conserving the historical Ottoman portico as well as the first 
legislation of heritage conservation policy in 1972 AD. The research uses a mixed approach of gathering data through a literature review as a secondary data and the primary sources which include official and non-official reports as well as government and non-government archive records in order to achieve the research aim.

\section{THE TRADITIONAL URBAN FABRIC THROUGH HISTORY}

First of all, it is important to know that urban extent of Mecca is constrained by surrounding mountains since the Holy Mosque is located in a low part of the city which called the valley of Ibrahim. Assaf and Barhamain [4] described the city of Mecca as it "is in the shape of a star with the mosque located in the center". The development of the city of Mecca went through a continuous process throughout the history where the rate of the development varied from one period to another (Fig. 1).
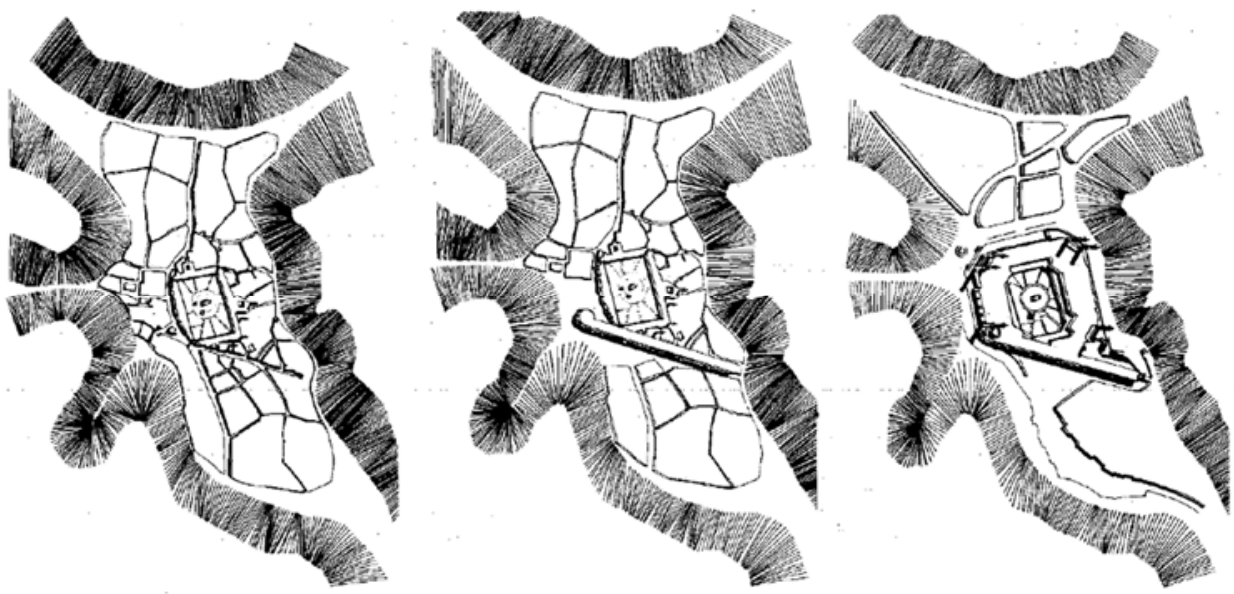

Figure 1: Mecca city from the period of Ottoman till 1975 AD. (Source: ACEP, 1977, p. 44.)

By the time of the prophet, the urban form of Mecca consisted of the "Ka'aba" with small houses around it. During the dynasties of Fatimid around 1517 AD the city became an example of Islamic town as the Holy Mosque and few markets and shops surrounded it represented the primary centre of the city, and houses at this certain period did not exceed two stories [5]. Throughout the Ottoman period (1572-1923 AD), the city of Mecca witnessed an obvious increase in buildings that include houses and public utilities, and multi-storey buildings were began to appear [5]. In 1923 AD when King Abdul Aziz established the Saudi rule, the city of Mecca observed a rapid growth as the expansion was began in all directions starting westward where the flatland is suitable for building [6]. In addition, by the year of $1975 \mathrm{AD}$, Mecca extended beyond the surrounding hills and a large number of multi-story buildings especially in the centre of the city had been raised [7].

\section{THE PILGRIMAGE (HAJJ) AND ITS IMPACT}

Pilgrimage is a widespread traditional concept in many religions that include Islam, Christianity, Jewish and Hindus. It has been estimated that around $60 \%$ of the population in the world practices a religion and, approximately 600 million national and international religious journeys are made every year around the world for spiritual motives [8]. Except for the Muslim, such visits are not obligatory. 
"And proclaim to the people the Hajj [pilgrimage]; they will come to you on foot and on every lean camel; they will come from every distant pass" [9].

The literal meaning of Hajj in Arabic "is to seek out towards a definite, variable objective" [4]. For Muslims, Hajj does not glorification any shrines or places that had been visited by the prophet Mohammed, However it is reform of the Prophet Ibrahim's actions where the connection is direct to God.

During the 1920s-1950s, the number of pilgrims to the city of Mecca was very limited due to the difficulty of the journey as it was depended on camel caravans, therefore, few pilgrims from other countries were able to perform the Hajj due to the long distance involved. As the journey on Hajj has become easy with the improvements in the field of transportation as pilgrims from other countries can get to the city of Mecca within hours by using airplanes while pilgrims from inside the country or even its neighbouring countries can reach Mecca more easily since the big improvement of road network. The number of visitors to Mecca has been growing rapidly during the last few decades (Fig. 2).

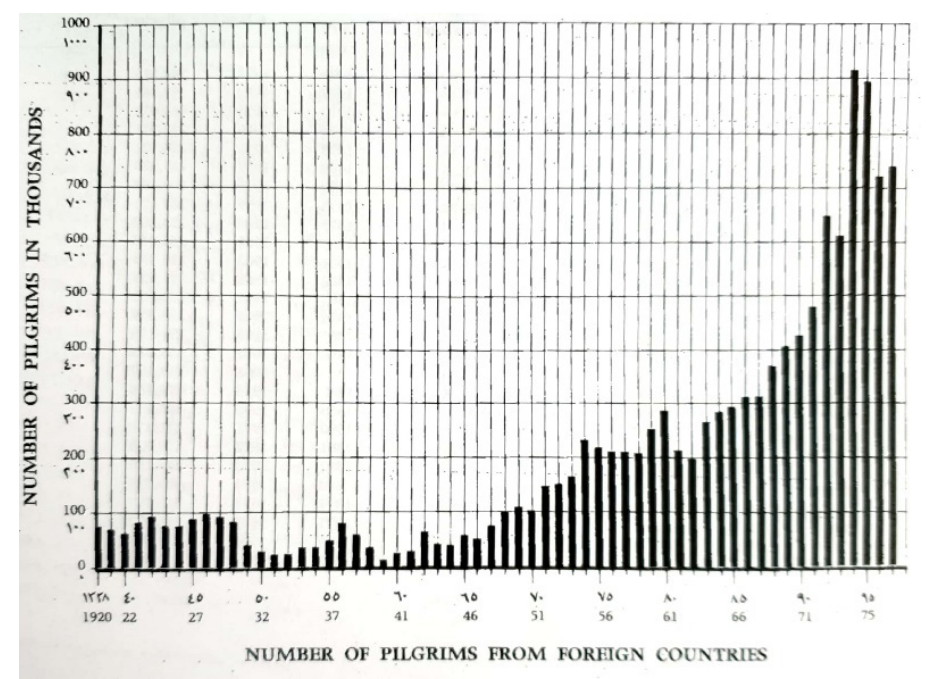

Figure 2: Number of pilgrims from foreign countries. (Source: ACEP, 1977, p. 104.)

In 1950 s, Mecca used to cater about 280,000 pilgrims, and that number has stretched to 2.9 million in $2011 \mathrm{AD}$ [6]-[10]. According to Taylor [11] Mecca is struggling to cope with 12 million pilgrims who visit each year, and by $2025 \mathrm{AD}$ that number expected to grow to 17 million. In addition, a target of 30 million pilgrims annually has been set as in the 2030 AD Saudi vision [12]. Based on that, and as the number of Muslims increased over the years, an extension to the holy mosque area became essential.

\section{THE EXPANSION OF THE HOLY MOSQUE}

First of all, it is important to know that the phenomenon of expansion projects of the holy mosque is not new. It has begun since the era of the Muslim caliphs particularly since the time of Umar Bin Al-Khattab (the second Caliph of Islam). As the Holy Mosque remains the focal point of the holy city of Mecca, it would be most useful to trace the expansion of such 
an important building throughout the history in order to give an idea about the magnitude of the expansion projects in the Saudi era.

\subsection{The history of expansion projects}

Back in history, at the time of the prophet, the holy mosque consisted of a circular plaza with about 2,100 $\mathrm{m}^{2}$ [7, p. 227]. In $637 \mathrm{AD}$, as the number of Muslims increased and the site became crowded, the Caliph Umar Bin Al-Khattab added about $1,500 \mathrm{~m}^{2}$ to its area after purchasing some adjacent houses to make the holy mosque cover $3,600 \mathrm{~m}^{2}$ [7, p. 227]. Hardly a decade later, another expansion carried out under the Caliph Uthman Bin Affan who increased the total area of the holy mosque to $4,482 \mathrm{~m}^{2}$ and the covered porticoes had been introduced for the first time [2, p. 31]. In $684 \mathrm{AD}$, the Caliph Abdullah Bin Zubair had further expanded the holy mosque to make the total area $7,465 \mathrm{~m}^{2}$ followed by the expansion in 709 AD that carried out by the Caliph Al-Waleed Bin Abdul-Malik who renovated the building and enlarged the area of the holy mosque by $2,800 \mathrm{~m}^{2}$ [7, p. 227].

In the Abbasid era, the Caliph Abu Jafar Al-Mansour in $754 \mathrm{AD}$, made a significant contribution in extending the holy mosque as he extended the area of the holy mosque twice as large as previous expansions. The Caliph Mohammed Al-Mahdi carried out further expansion in two phases (776-781 AD) to make the total area of the holy mosque to be about $28,000 \mathrm{~m}^{2}$ [7, p. 227]. With this increase, the holy mosque attained its maximum size in area, except for two small external addition.

In $897 \mathrm{AD}$, the Caliph Al-Muatad carried out the first small expansion known as (Bab Al-Zeyada) in the north-eastern side of the holy mosque while the second one (Bab Ibrahim) was introduced by the Caliph Al-Muqtader in $918 \mathrm{AD}$ in the south-western side [7, p. 227]. The holy mosque witnessed no further expansion for more than one thousand years, however, it had rebuilt in $1576 \mathrm{AD}$ by the Ottoman Sultan who replaced the flat roof with 500 domes known as the Ottoman portico [2, p. 36], [7, p. 227]. The size and layout of the holy mosque maintained exactly until the first Saudi expansion. Fig. 3 shows the historical expansions of the Holy Mosque.
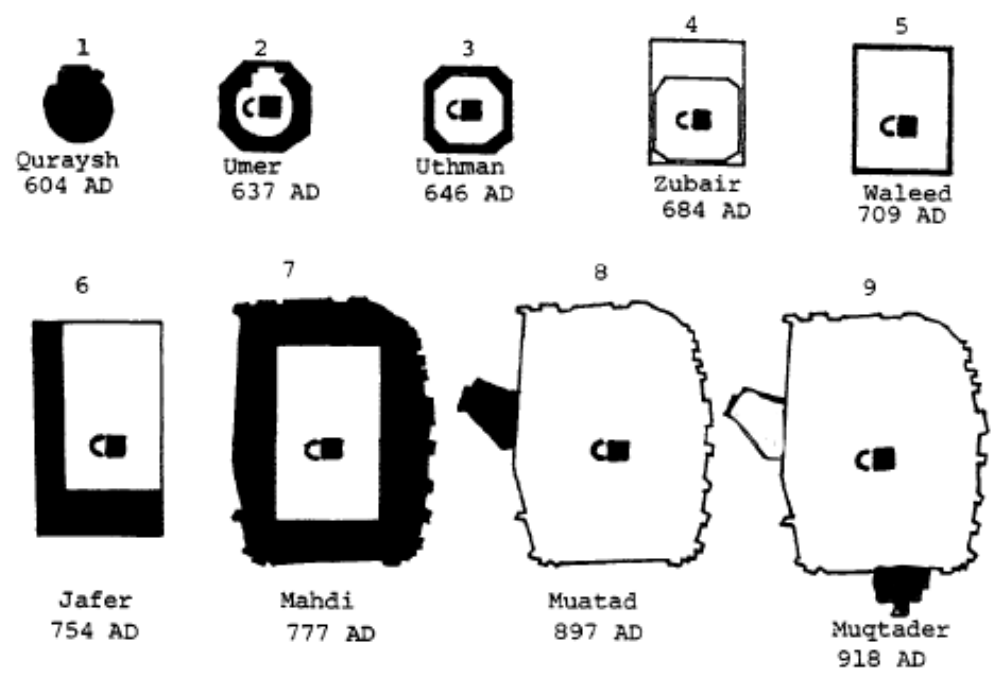

Figure 3: The expansion of the Holy Mosque through the eras. (Source: ACEP, 1977, p. 28.) 


\subsection{First Saudi expansion (1955-1979 AD)}

The structure of the holy mosque at the time when King Abdul Aziz established the Saudi rule was the one that constructed by the Ottoman Sultan in 1576 AD which means the holy mosque had remained unaltered for about four hundred years except for periodic repairs [2, p. 38]. However, the emergence of numerous independent Islamic States after the World War II along with the fact that the journey of Hajj became much easier than before led the government of Saudi Arabia to start thinking of expansion the holy mosque. Thus, in mid-December, 1955 AD the first expansion in the Saudi era had launched by King Saud starting by demolishing the buildings around the holy mosque [7, p. 227]. Due to the immensity of the undertaking, the expansion project was distributed over two decades where its implementation was divided into four major phases shown in Fig. 4 [2, p. 47].
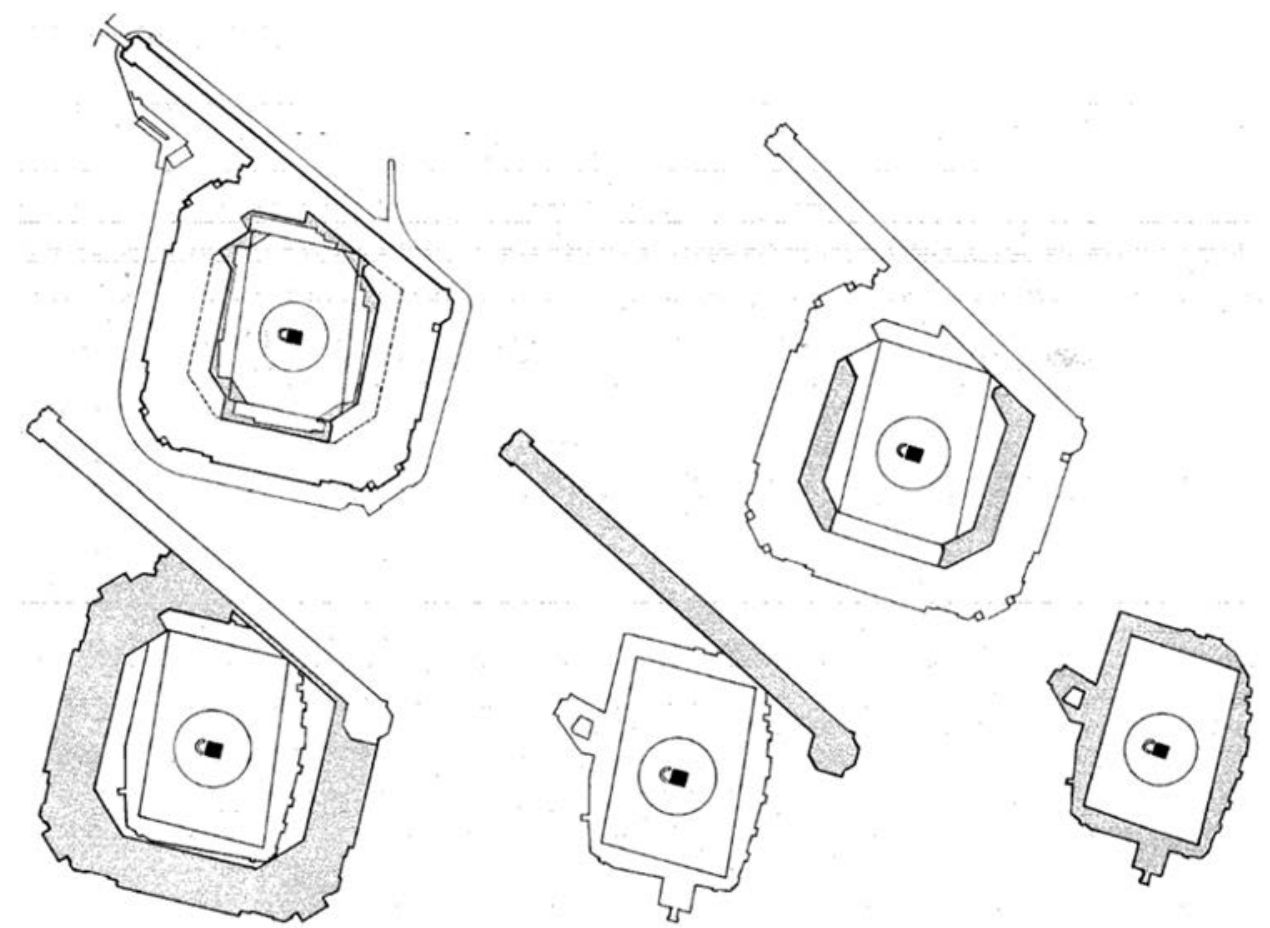

Figure 4: The phases of construction for the first expansion. (Source: ACEP, 1977, p. 46.)

In phase one, the section between "Safa" and "Marwa" was established over the existing pathway where the construction of the new external mosque was completed in phase two. Phase three was started by a very careful decision of King Faisal to conserve the Ottoman portico, and the "Mukabbaria" and new peripheral roads were constructed in this phase. In phase four, the renovation work of the old mosque was completed after reconstructing the dismantled parts in the same architectural style [2, p. 47].

By $1979 \mathrm{AD}$, the first expansion project was completed and the total area of the holy mosque had reached $160,000 \mathrm{~m}^{2}$ to accommodate 460,000 prayer [13]. However, in order for this project to be completed, houses and buildings in "Massa" and "Ajyid" area were 
demolished (Figs 5 and 6). Because of the paucity of alternate accommodation in Mecca city, people who inhabited these buildings were shifted gradually. The total demolishing work in this project has recorded as $1,301,100 \mathrm{~m}^{3}$ [2, p. 147].

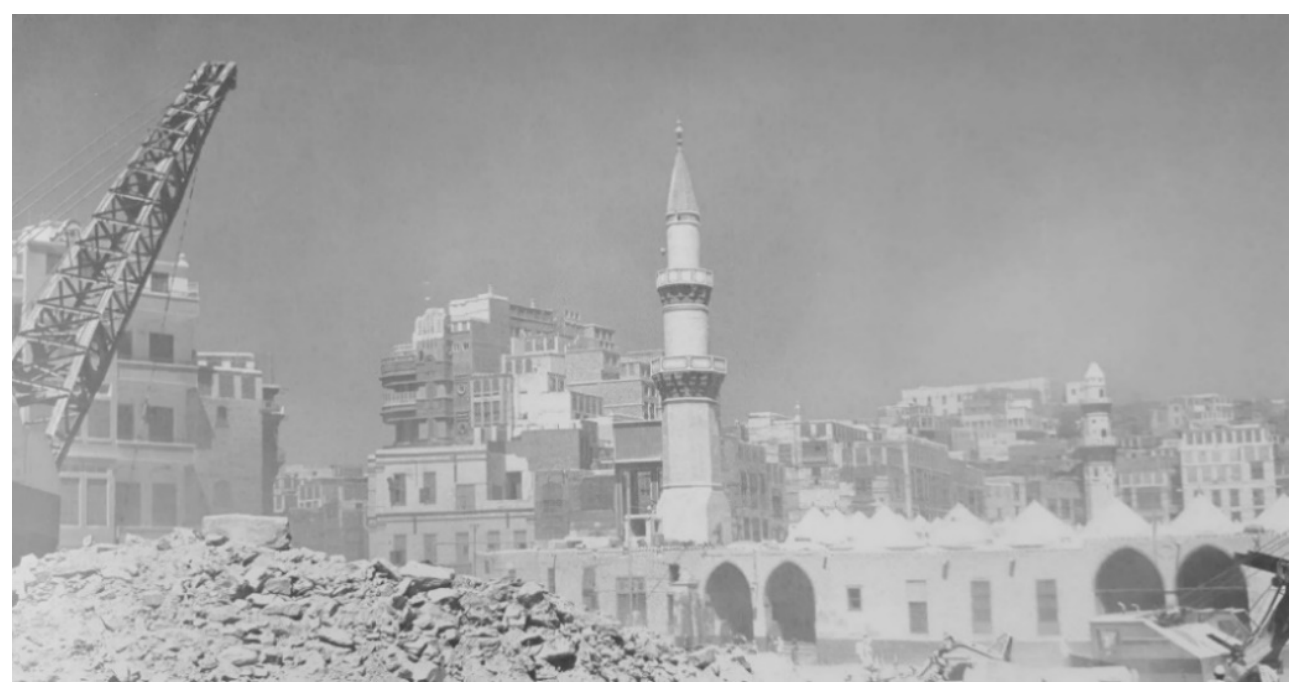

Figure 5: Demolition on the south side of Holy Mosque. (Source: Mirza, 2016, p. 234.)

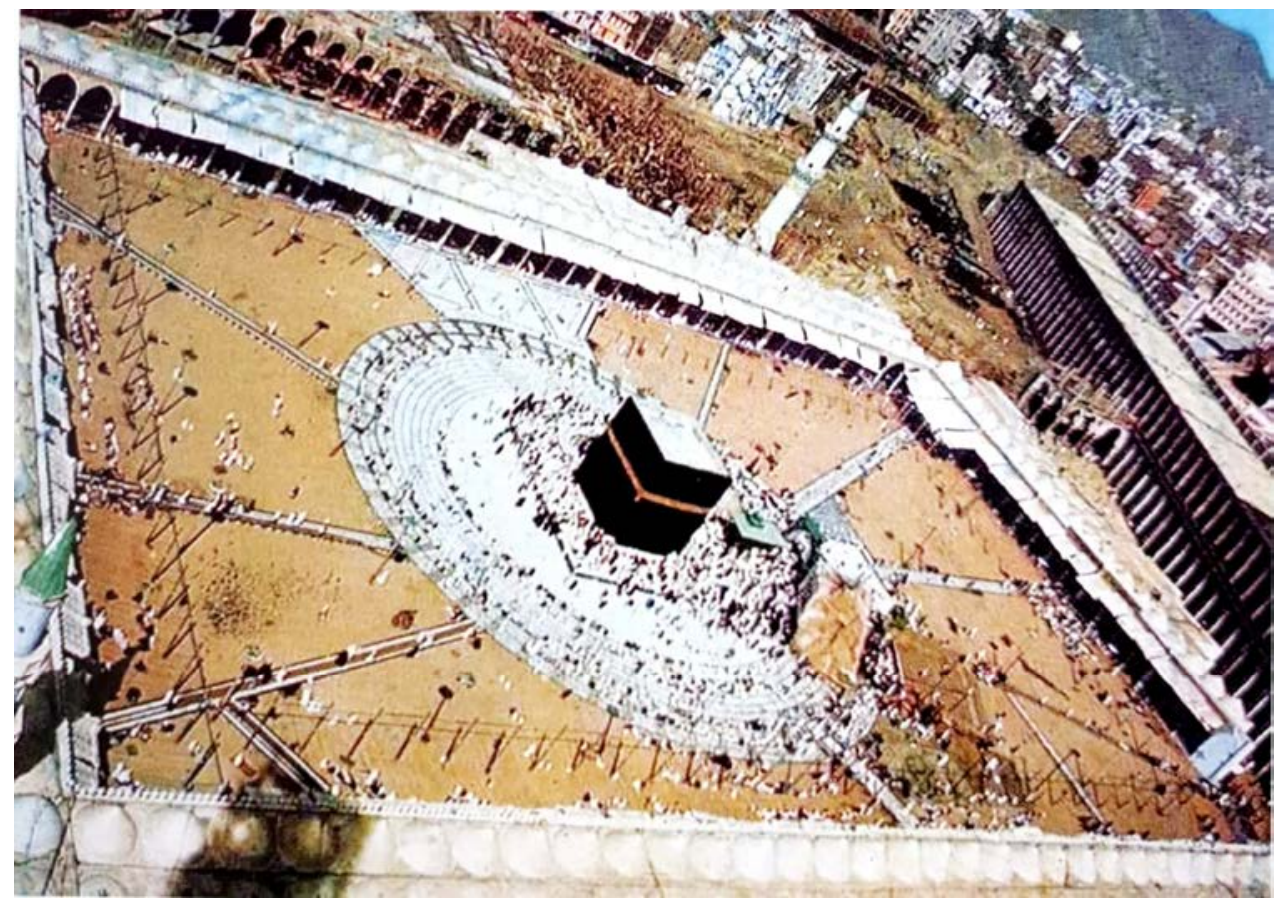

Figure 6: The construction work of the first Saudi expansion. (Source: Mirza, 2016, p. 239.) 


\subsection{Second Saudi expansion (1988-1993 AD)}

The beginning stages of this expansion started by demolishing $30,000 \mathrm{~m}^{2}$ in the western side of the holy mosque where this area has been set up as temporary prayer plaza before construction work begins on it [13]. In 1988 AD, King Fahd laid the foundation stone for the second Saudi expansion of the holy mosque. A semi-circular building was joined the holy mosque from the western side while some considerable improvement carried out on all parts of the holy mosque that include the installation of escalators to carry worshippers to the second floor and rooftop [7, p. 273]. The project was added $57,000 \mathrm{~m}^{2}$ on the western side of the holy mosque along with $88,000 \mathrm{~m}^{2}$ of the surrounding plaza (Fig. 7) to enable worshippers to perform their rites during the high seasons which made the total area of the holy mosque reached $366,168 \mathrm{~m}^{2}[13]$.

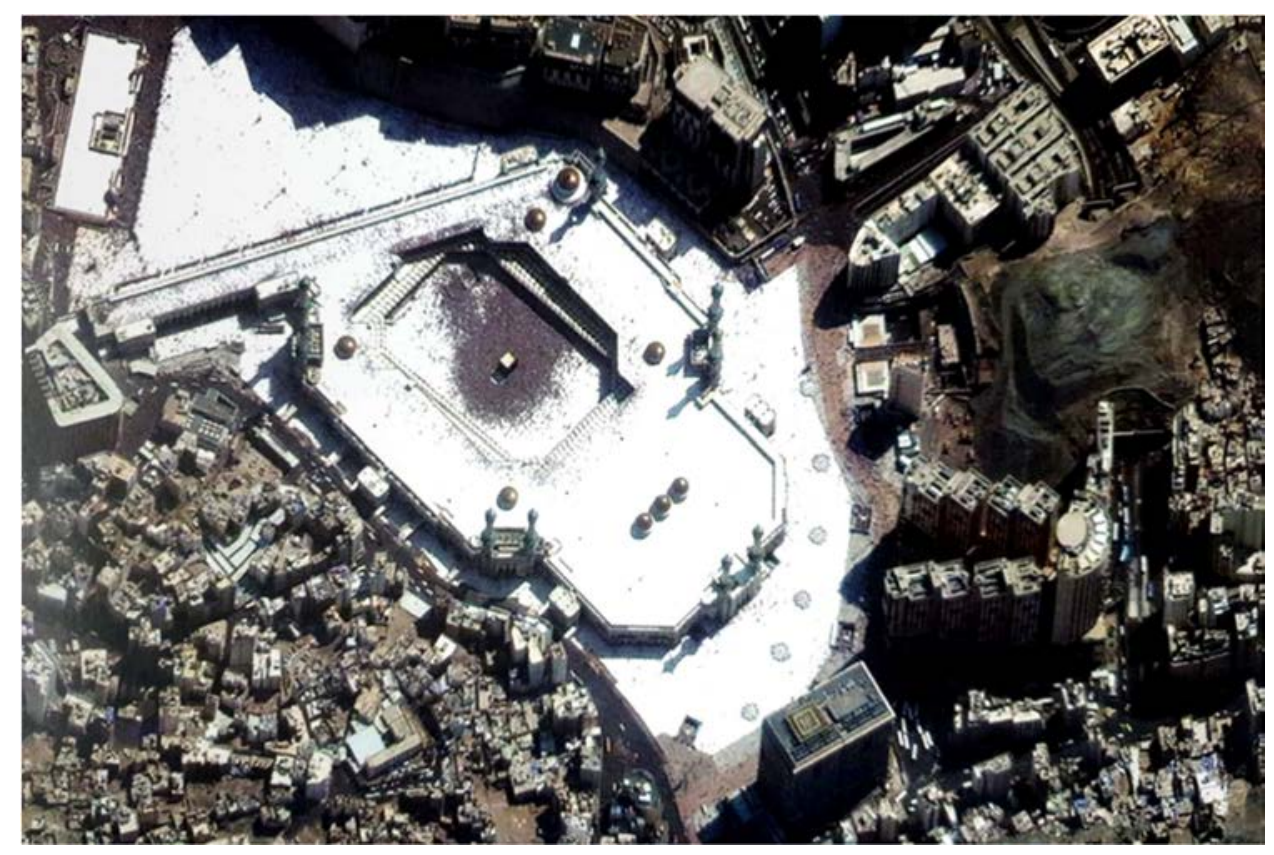

Figure 7: The second Saudi expansion after completion. (Source: Mirza, 2016, p. 289.)

\subsection{Third Saudi expansion (2010-2018 AD)}

Due to the rapid growth of the visitor number to the holy city of Mecca during the last few decades, King Abdullah issued a royal decree in 2010 AD to embark on a new expansion of the holy mosque in the northern side. The expansion added $320,000 \mathrm{~m}^{2}$ as a prayer area while $175,000 \mathrm{~m}^{2}$ was added to the surrounding plaza (Fig. 8) [14], [15]. Besides the new prayyards, the new expansion also comprised walkways, tunnels and the development of existing service facilities. This project can be considered as one of the largest project worldwide based on capacity as it designed to accommodate by One million prayers at the same time with all required facilities [14]. However, the expansion project was done at the cost of demolishing 5,882 buildings with the total area of $300,000 \mathrm{~m}^{2}$ (Fig. 9) as it extended the holy mosque to a depth of 380 meters [15], [16]. 


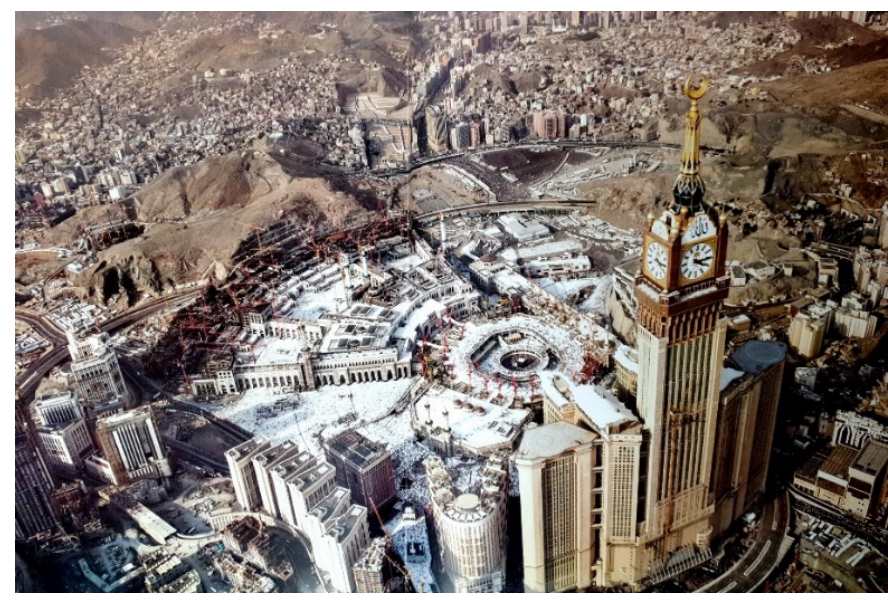

Figure 8: The third Saudi expansion during construction in 2015 AD. (Source: Mirza, 2016, p. 305.)

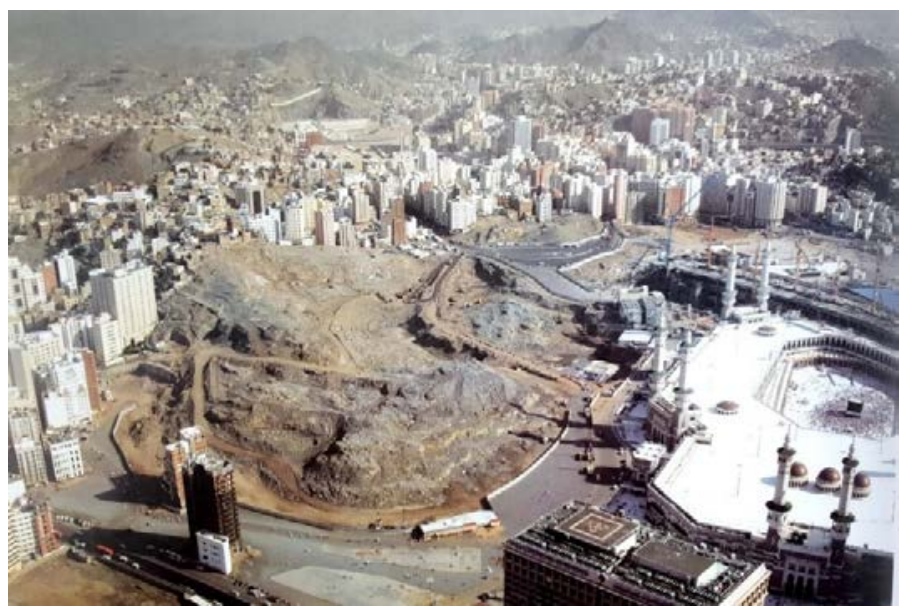

Figure 9: The demolishing area in the northern side to expand the Holy Mosque. (Source: Mirza, 2016, p. 301.)

\section{CONSERVING THE OTTOMAN PORTICO}

The initial designing of the first expansion project of the holy mosque (by Architect Taher Goveni) was based on the assumption that the old mosque would be removed (Fig. 10). However, when the construction work of the outer half of the new structure was completed (Fig. 11), a major change in the design was introduced as King Faisal ordered that the 400 years old Ottoman portion should not be demolished [2, p. 113]. Thus, the Government of Saudi Arabia invited of some famous international architects and engineers from the various Islamic countries (Iran, Morocco, Saudi Arabia, Iraq, Turkey, India, and Egypt) to a meeting in order to acquaint them with the architectural aspects of the old structure and to undertake the necessary studies along with submitting their proposal in this respect [2, p. 159]. 


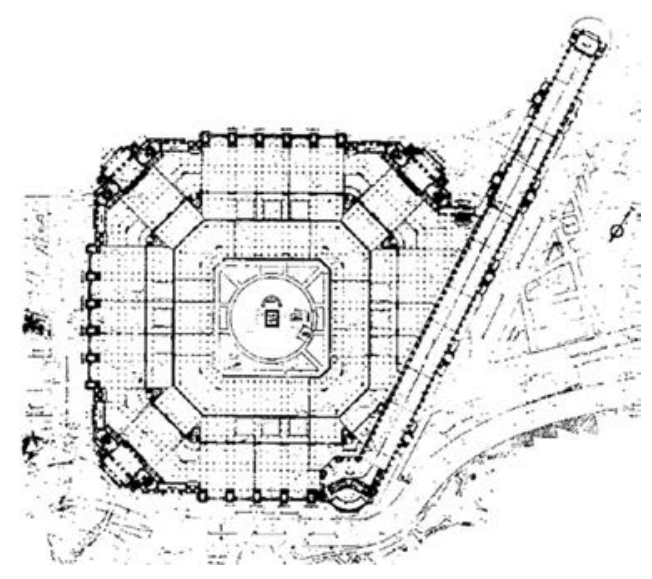

Figure 10: The first approved plan. (Source: ACEP, 1977, p. 47.)

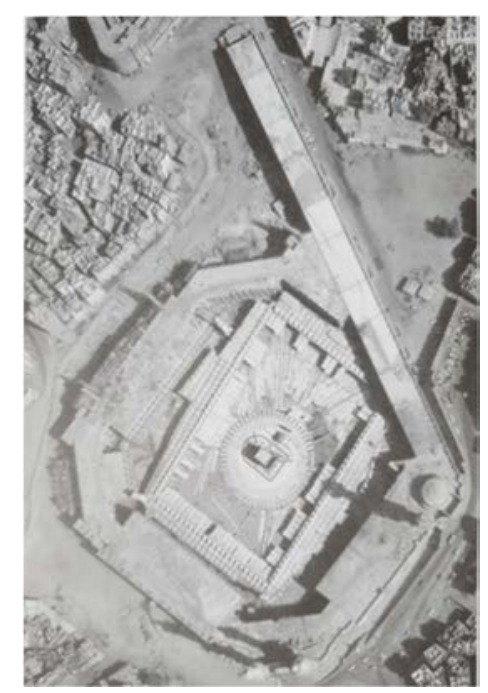

Figure 11: The Holy Mosque prior to the connection with old structure in 1965. (Source: Mirza, 2016, p. 253.)

The meeting was held in the city of Mecca in 1967 AD. The committee noted that the portico had lasted its expected period of life and conserving it would require major repairs which costing a lot. Thus, they recommended that except a small part between "Bab Malik" and "Bab Al Omra", the Ottoman structure need to be demolished and the new construction should be extended in its place. However, King Faisal did not favour the demolishing of the 400 years old Ottoman structure [2, p. 112]. Mindful of his position as custodian of the Holy Mosque and regardful of the sentiments of the world's pilgrims he directed that "the historical Ottoman structure should not be dismantled; instead, the challenge of retaining it and harmonizing it with the new structure should be met; measures should be taken to preserve the Ottoman Mosque and remedy the defects that had appeared in the structure due 
to ageing, irrespective of consideration of cost involved in this effort" [17]. Therefore, the design was modified, as shown in Fig. 12, with a view to combining the new building with the existing Ottoman structure, retaining the old familiar look of the mosque as seen from the "Mataf" [2, p. 113]. Fig. 13 shows the Holy Mosque after completing the connection with old structure.

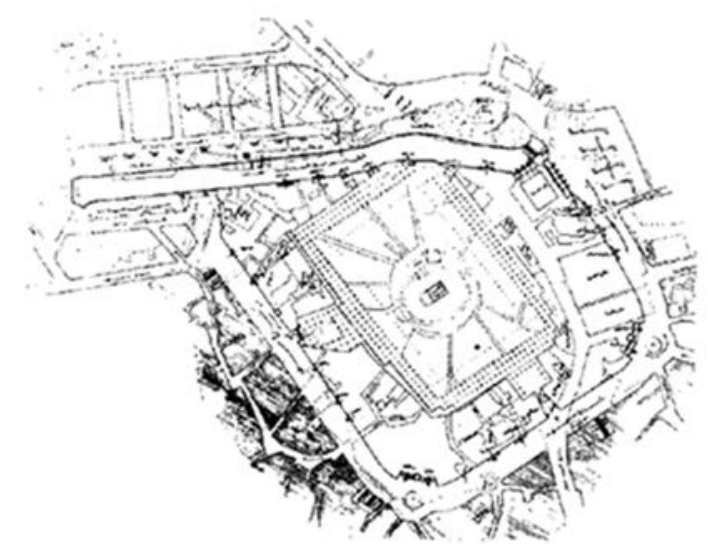

Figure 12: Taher Goveni's sketch for the updated design. (Source: ACEP, 1977, p. 47.)

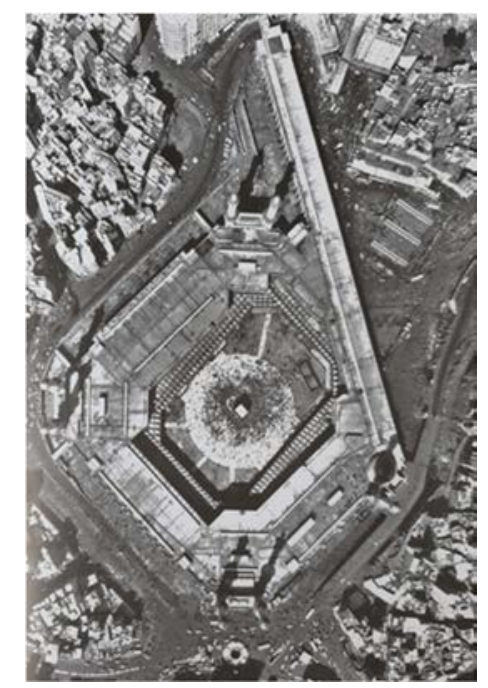

Figure 13: The Holy Mosque after completing the connection with old structure in 1975. (Source: Mirza, 2016, p. 254.)

\section{THE FIRST LEGISLATION OF HERITAGE CONSERVATION}

Few years later, the first conservation legislation was issued by the Royal Decree (M/26) in 3.8.1972 AD along with the establishment of The Supreme Council for Antiquities under The Minister of Education [18]. The conservation legislation called "Regulation for Antiquities" 
is comprehensive legislation as it includes regulation for both fixed and movable antiquities. The Regulation for Antiquities is divided into seven chapters, in which each chapter is subdivided into articles that run through the entire text successively [18]. Although one chapter out of the seven is for the conservation of historical buildings and sites, it includes rules for the conservation that covering aspects such as the criteria for identifying a historic building, the acquisition rules as well as the preservation procedures [18, chapter 2]. The criteria used to determine an object's significance are its age and its historical and artistic value. buildings and structures which have more than 200 years in its age or less than this age but got historic or artistic value are considered archaeological artefacts [18, article 5, $\mathrm{M} / 26]$. However, these regulations are not fully applied in case of Mecca particularly around the holy mosque. Therefore, the need for a special regulation for the holy cities (Mecca and Madinah) is initial in order to conserve what has been left.

\section{CONCLUSION}

In general, Religious events which gather huge number of people at a specific time and in specific location will lead to several impacts on society, culture, and economy [19]. The situation is more complicated in the case of Islamic pilgrimage since Hajj is an extraordinary event that happing every year in the city of Mecca which considered as the spiritual capital of more than one and half billion Muslims and being visited by millions of pilgrims every year [4]-[6]. During the past decades, the holy mosque, in Mecca, Saudi Arabia has witnessed enormous expansions in line with the steady growth in the number of visitors and pilgrims to this honourable spot of land. In turn, these expansions have led to the demolition of several buildings with architectural and historical value that surrounding the holy mosque to facilitate the implementation of this project, resulting in a major shift in the geographical and historical composition of this region [16]. Despite the first legislation of heritage conservation policies approved in 1972 AD which led to some conservation project around the kingdom (AlDiriyah and Historical Jeddah), the situation in Mecca is more complicated especially the centre where the holy mosque located as the demand of visitors increasing annually to this honourable spot of land.
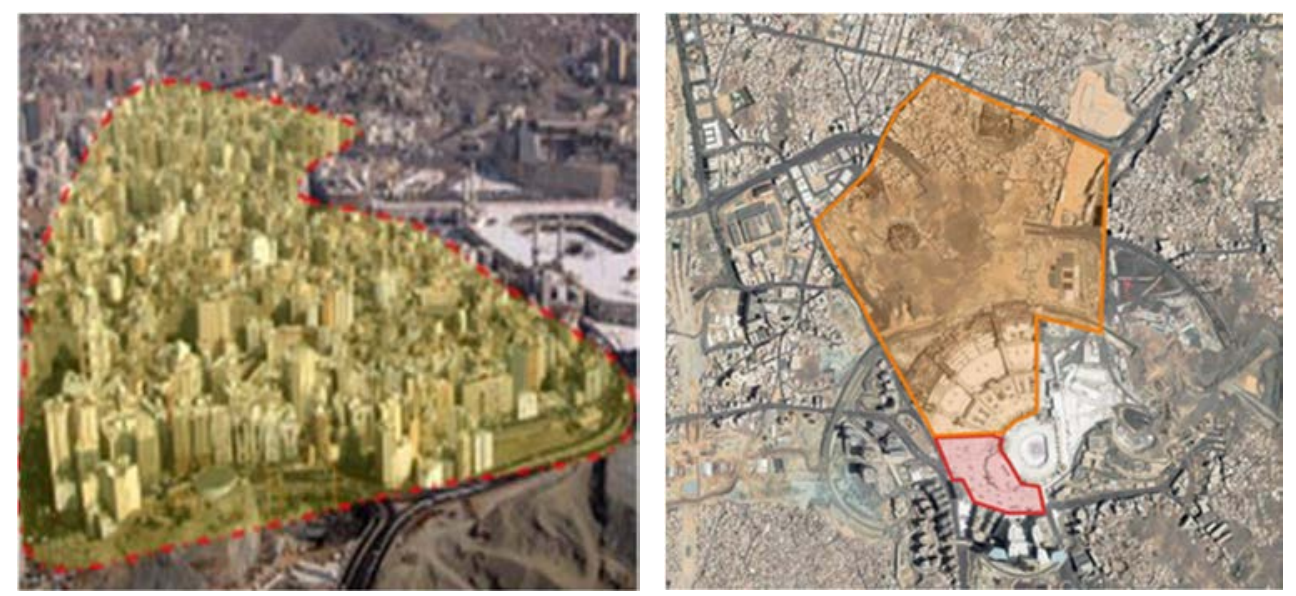

Figure 14: The demolished neighbourhoods and the changes in the urban fabric of the city. (Source: Alsabban, 2018.) 


\section{REFERENCES}

[1] Page, S., Mecca: The "blessed heart" of Islam. Between Cultural Diversity and Common Heritage: Legal and Religious Perspectives on the Sacred Places of the Mediterranean, Routledge: Abingdon and New York, pp. 319-330, 2014.

[2] The Association of Consulting Engineers Pakistan (ACEP), The expansion and construction of Holy Mosque. Ministry of Finance: Riyadh, 1977.

[3] Nasr, S.H., Mecca The Blessed, Medina The Radiant: The Holiest Cities Of Islam, Tuttle Publishing: Tokyo, Rutland and Singapore, 2013.

[4] Assaf, S.A. \& Barhamain, S.Y., Factors affecting construction practices in Makkah Al-Mukkaramah, Saudi Arabia: Detailed survey of randomly selected contractors, consultants and government agencies revealed ten major factors. Building Research and Information, 24(1), pp. 27-30, 1996.

[5] Al-Siba'i, A., History of Makkah, King Fahad National Library: Riyadh, 1999 [in Arabic].

[6] Ascoura, I.E., Impact of pilgrimage (Hajj) on the urban growth of the Mecca. Journal of Educational and Social Research, 3(2), pp. 255-263, 2013.

[7] Mirza, M.N., Shawush, A.S. \& Mirza, M.M., The Digital Illustrated Atlas of Makkah and the Holy Environs: From the 11th Century to the Present, Umm al-Qura University: Makkah, 2016.

[8] UNWTO, Religious tourism in Asia and the Pacific, World Tourism Organization: Madrid, 2011.

[9] Surah Al-Hajj, The Holy Qoran, verse 27.

[10] Khan, H.U., Architectural conservation as a tool for cultural continuity: A focus on the built environment of Islam. International Journal of Architectural Research, 9(1), pp. $1-17,2015$.

[11] Taylor, J., Medina: Saudis take a bulldozer to Islam's history. The Independent, 2012. www.independent.co.uk/news/world/middle-east/medina-saudis-take-a-bulldozer-toislams-history-8228795.html. Accessed on: 12 Mar. 2020.

[12] Government of Saudi Arabia, Saudi Arabia Vision 2030, 2016.

[13] Al-Sebial, M., The Two Holy Mosques, Expansions and Services Within A Hundred Years, 1st ed., The General Presidency for the affairs of Grand Mosque and the Prophet's Mosque, 1998 [in Arabic].

[14] Saudi Press Agency, The third Saudi expansion, a historical move for the Grand Mosque. Report, 2015. www.spa.gov.sa/1380351?lang=ar\&newsid=1380351, Accessed on: 8 Mar. 2020 [in Arabic].

[15] Ghamdi, Z., Grand Mosque third expansion, Saudi Projects. https://saudiprojects.net/?project=توسعة_الملك-عبدالهـ_للمسجد_الحرام. Accessed on: 25 Feb. 2020 [in Arabic].

[16] Alsabban, R.F. \& Fatani, M.A., Using multimedia in documenting and archiving the islamic architectural heritage of the holy mosque area in Makkah city, Saudi Arabia. WIT Transactions on The Built Environment, vol. 177, pp. 63-74, 2018.

[17] Kingdom of Saudi Arabia, Royal Decree No. 257, Mecca, 1969.

[18] Kingdom of Saudi Arabia, Royal Decree No. M/26, (Regulation for Antiquities), Riyadh, 1972.

[19] Marine-Roig, E., The impact of the consecration of "La Sagrada Familia" basilica in Barcelona by Pope Benedict XVI. International Journal of Tourism Anthropology, 5(1-2), pp. 95-115, 2016. 